\title{
49. Group Characteristics of RNA Phages
}

\author{
By Itaru Watanabe, *) Tohru Nishihara,*) Hiroshi Kaneko, ${ }^{*}$ \\ Toshizo SakuraI, ${ }^{*)}$ and Satoshi OsaWA**) \\ (Comm. by San-ichiro Mizushima, M.J.A., March 13, 1967)
}

Introduction. As reported by Watanabe et al. (1967), RNA phages were separated in three groups both by a serological method and a Millipore filtration method. This fact indicates that there are at least three types of coat proteins in known RNA phages. Based on this grouping, we attempted to determine the group characteristics of RNA phages from various aspects.

In this paper, we present chemical and physical properties of RNA phages, such as UV sensitivity, density, sedimentation constant, tryptophan content, base ratio and $\mathrm{pH}$ sensitivity. Although some of them are still preliminary, the data suggested that these three groups show differences not only in the properties of coat protein, but in the size and the nature of RNA. Experiments to relate differences in proteins and those in RNA are now in progress.

$U V$ sensitivity. In order to test UV sensitivity of RNA phages, a phage lysate containing $10^{11}-10^{12} \mathrm{PFU}$ per $\mathrm{ml}$ was diluted in trissalts medium (Miyake et al. 1966) so as to contain about $10^{8} \mathrm{PFU}$ per $\mathrm{ml}$. Five $\mathrm{ml}$ of this phage suspension was irradiated by UV ("National" GL-15, $15 \mathrm{Watt}, 20 \mathrm{~cm}$ ), and the sample was taken at various time and assayed for survivors. Results were shown in Fig. 1, where UV sensitivity was plotted as a ratio of surviving PFU to original PFU. As shown in Fig. 1, RNA phages were separated in three groups based on their UV sensitivity, and such grouping was in good accordance with grouping by the serological method and the Millipore filtration method. In other words, RNA phages of group I were fairly resistant to UV irradiation and those of group III were most sensitive to UV and those of group II showed inbetween sensitivity. It should be emphasized, however, that our grouping both by the serological method and the Millipore filtration method was based on the properties of coat protein, and therefore no direct relation between our grouping and UV sensitivity could be expected.

Density. To test buoyant densities of RNA phages, partially purified samples of several phage strains were run by $\mathrm{CsCl}$ density gradient centrifugation (Spinco Model L2, rotor SW 39, 37,000 rpm,

*) Department of Molecular Biology, School of Medicine, Keio University.

**) Department of Biology, Showa University. 


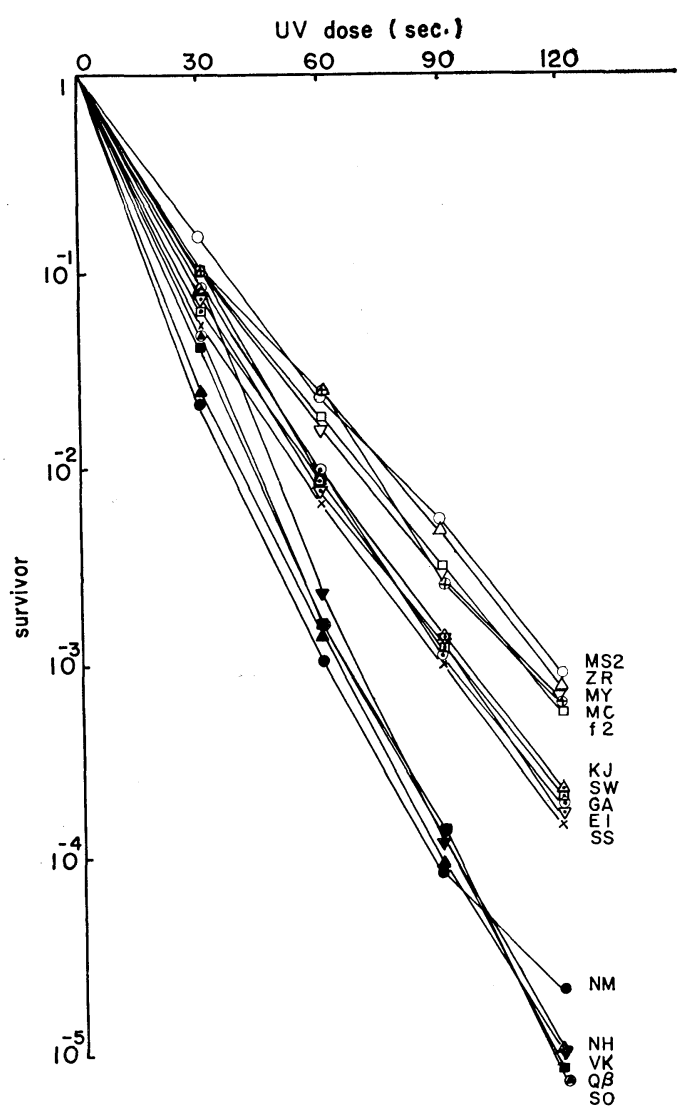

Fig. 1. UV sensitivity of RNA phages.

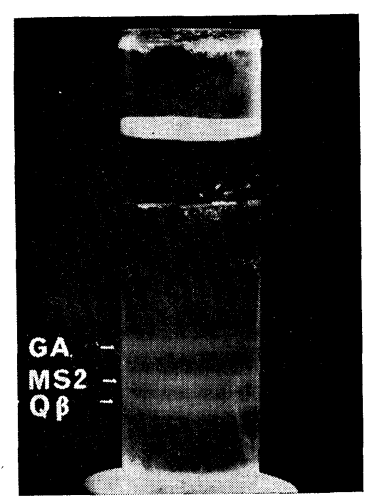

Fig. 2. Separation of RNA phages, MS2 (I), GA (II), and $\mathrm{Q} \beta$ (III) in $\mathrm{CsCl}$ gradient.
30 hours). After centrifugation, each drop collected from bottom of the tube was assayed for PFU and for UV absorption. The result indicated that the visible band was formed by active phage particles. As materials, six strains of RNA phage, MS2 (I), MY (I), GA (II), SD (II), Q $\beta$ (III), and VK (III) were used as representatives of each group.

The result of such banding experiment was shown in Fig. 2, and the buoyant densities of these RNA phages calculated from the position of the band were summarized in Table I. As shown in Fig. 2 and Table I, RNA phages which belonged to different groups were separately banded by this method, while those of the same group were banded in the same position. In other words, the 
Table I. Chemical and physical properties of RNA phages

\begin{tabular}{|c|c|c|c|c|c|c|c|}
\hline & phage & density & $\mathrm{s}$-value & $\begin{array}{r}\mathrm{RN} \\
\mathrm{A}+\mathrm{C} \\
\mathrm{G}+\mathrm{U}\end{array}$ & $\begin{array}{c}\text { base } \\
\frac{\mathrm{A}}{\mathrm{U}}\end{array}$ & $\begin{array}{l}\text { ratio } \\
\mathrm{G}+\mathrm{C} \%\end{array}$ & $\begin{array}{c}\text { tryptophan } \\
\text { content }\end{array}$ \\
\hline group I & $\begin{array}{c}\text { M S } 2 \\
\text { M Y }\end{array}$ & $\begin{array}{c}1.457 \\
\text { " }\end{array}$ & $79 \mathrm{~S}$ & $\begin{array}{l}1.00 \\
0.97\end{array}$ & $\begin{array}{l}0.98 \\
0.95\end{array}$ & $\begin{array}{l}52.2 \\
52.1\end{array}$ & $\begin{array}{l}+ \\
+\end{array}$ \\
\hline group II & $\begin{array}{l}\text { G A } \\
\text { S D }\end{array}$ & $\begin{array}{c}1.442 \\
\prime \prime\end{array}$ & $76 \mathrm{~S}$ & $\begin{array}{l}0.94 \\
0.92\end{array}$ & $\begin{array}{l}0.86 \\
0.84\end{array}$ & $\begin{array}{l}48.3 \\
48.3\end{array}$ & $\begin{array}{l}++ \\
++\end{array}$ \\
\hline group III & $\begin{array}{l}\mathrm{Q} \beta \\
\mathrm{VK}\end{array}$ & $\begin{array}{c}1.469 \\
\prime \prime\end{array}$ & $83 \mathrm{~S}$ & $\begin{array}{l}0.87 \\
0.88\end{array}$ & $\begin{array}{l}0.79 \\
0.78\end{array}$ & $\begin{array}{l}47.6 \\
47.7\end{array}$ & $\begin{array}{l}- \\
-\end{array}$ \\
\hline
\end{tabular}

buoyant densities $1.442,1.457$, and 1.469 were very characteristic to group II, I, and III, respectively. So far, no phage which was banded in the forth position was isolated.

Sedimentation constant. Sedimentation constants of RNA phages MS2 (I), GA (II), and $\mathrm{Q} \beta$ (III) were determined in $0.01 \mathrm{M}$ tris buffer ( $\mathrm{pH}$ 7.6) containing $0.14 \mathrm{M} \mathrm{NaCl}$ (Spinco Model E, $23150 \mathrm{rpm}$ ). As shown in Table I, S values of MS2, GA, and $Q \beta$ were $79 \mathrm{~S}, 76 \mathrm{~S}$, and $83 \mathrm{~S}$, respectively. This result indicated that particle size of these three phages were significantly different. The experiment to show whether these $\mathbf{S}$ values were characteristic to each group or not is now in progress.

Tryptophan content. Content of tryptophan in six different RNA phages MS2 (I), MY (I), GA (II), SD (II), Q $\beta$ (III), and VK (III) was determined by p-dimethyl-aminobenzaldehyde method (Spies and Chamber 1948, 1949). As shown in Table I, Q $\beta$ and VK contained virtually no tryptophan and MS2 and MY contained approximately half of that in GA or SD. These results indicated that tryptophan content in coat protein was another group characteristics of RNA phages.

Base ratio. Base ratios of RNA from MS2 (I), MY (I), GA (II), SD (II), Q $\beta$ (III), and VK (III) were determined by paper chromatography. Details of procedure to prepare RNA samples and to determine base ratios are published elsewhere. Results shown in Table I indicated that these six RNA phages were separated in three groups also in this aspect, and that the phages of group II had inbetween base ratios. This fact suggested that GA or SD was not a mutant of MS2 (or MY), although these phages showed a weak inter-group reaction serologically (Watanabe et al. 1967).

$p H$ sensitivity. We also measured $\mathrm{pH}$ sensitivity of RNA phages. For this purpose, the inactivation kinetics of MS2 (I), MY (I), GA (II), $\mathrm{SD}$ (II), $\mathrm{Q} \beta$ (III), and VK (III) at various $\mathrm{pH}$ was traced. A buffer 


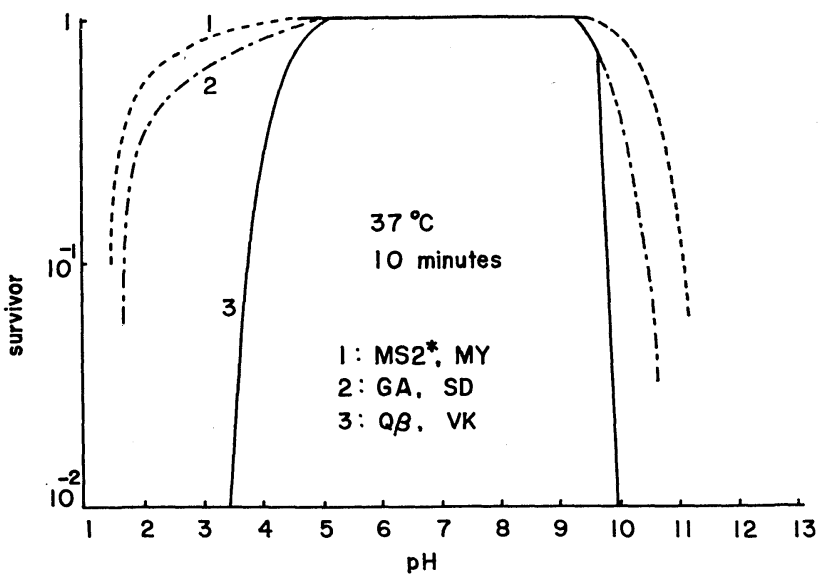

Fig. 3. pH sensitivity of RNA phages.

solution used for low $\mathrm{pH}$ was sodium actate- $\mathrm{HCl}$ and that for high $\mathrm{pH}$ was borate-NaOH. As shown in Fig. 3, RNA phages so far tested had characteristic patterns of $\mathrm{pH}$ sensitivity.

Summary. Chemical and physical properties of RNA phages, such as UV sensitivity, density, sedimentation constant, tryptophan content, base ratio and $\mathrm{pH}$ sensitivity, were studied. In these aspects, the values were characteristic to each group.

Acknowledgement. The authors express their thank to Dr. N. Ui for cooperation in determination of S values. They also thank Dr. H. K. Kihara and Dr. T. Miyake for valuable discussions and Mr. K. Furuse for cooperation in part of this experiment.

\section{References}

T. Miyake, K. Yanagisawa, and I. Watanabe (1966) : Jap. J. Microbiol., 10, 141-148.

J. R. Spies, and D. C. Chamber (1948): Anal. Chem., 20, 30.

- (1949): Anal. Chem., 21, 1249.

I. Watanabe, T. Miyake, T. Sakurai, T. Shiba, and T. Ohno (1967): Proc. Japan Acad,, 43, 204-209. 